\title{
HUBUNGAN PERILAKU PROSOSIAL DAN RELIGIUSITAS DENGAN MORAL PADA REMAJ A
}

\author{
Julia Aridhona \\ Universitas Muhammadiyah Malang \\ juliaaridhona0707@gmail.com
}

\begin{abstract}
Abstrak
Penurunan moral merupakan isu yang paling penting untuk diperbincangkan, berbagai macam pengaruh yang dapat menurunkan perkembangan moral seseorang, terlebih pada usia remaja yang merupakan masa yang terjadinya perubahan yang sangat pesat yang mudah terpengaruh oleh lingkungannya. Tujuan dari penelitian ini untuk mengetahui hubungan perilaku prososial dan religiusitas dengan moral pada remaja. Penelitian ini menggunakan subjek remaja dengan jumlah 100 orang yang berada di SMP, yang terdiri dari usia 13 sampai 16 tahun. Penelitian ini menggunakan teknik kuota sampling. Data dikumpulkan melalui kuisioner yang terdiri dari pembagian kuisioner perilaku prososial, religiusitas, dan moral dengan menggunakan skala likert. Analisis korelasi ganda yang digunakan untuk mengetahui adanya hubungan prososial dan religiusitas dengan moral pada remaja. Hasil analisis menunjukan ada hubungan positif antara perilaku prososial, religiusitas, dan moral yang artinya semakin tinggi perilaku prososial dan religousitas maka semakin bagus pula moral yang dimiliki remaja. Perilaku prososial yang tinggi menunjukkan bahwa remaja tengah mengalami perkembangan moral dalam rentang kehidupannya sebagai manusia. Moral yang tinggi juga mempengaruhi tingginya religiusitas yang tinggi menunjukkan bahwa remaja telah mampu menyesuaikannya. Hubungan yang signifikan menunjukkan moral pada remaja dapat dipengaruhi oleh perilaku prososial dan religiusitas yang remaja kembangkan selama masa remaja. Faktor-faktor lain yang mempengaruhi moral diluar perilaku prososial dan religiusitas seperti usia, kelas sosial ekonomi, relasi sosial dan faktor kepribadian.
\end{abstract}

Kata kunci : moral, perilaku prososial, religiusitas.

\begin{abstract}
Moral decline is the most important issue to discuss, a variety of influences that can reduce the moral development of a person, especially in adolescence which is a period of rapid changes that are easily influenced by the environment.The purpose of this study to determine the relationship between prosocial behavior and religiosity with morale in adolescents. This study uses the subject of teenagers with the number of 100 people who are in junior high school, which consists of ages 13 to 16 years. This research uses quota sampling technique. Data were collected through questionnaires comprising the distribution of questionnaires of prosocial, religiosity and moral behavior by using Likert scale. Multiple correlation analysis used to know the existence of prosocial relationship and religiosity with morale in adolescent. The result of the analysis shows that there is a positive correlation between prosocial, religiosity and moral behavior which means that the higher the prosocial and religiosity behavior, the better the morale the teenagers have. High prosocial behavior shows that adolescents are experiencing moral development in the span of life as a human being. Higher morale also affects the high religiosity indicates that adolescents have been able to adapt it. Significant relationships indicate morale in adolescents can be affected by prosocial behavior and religiosity that adolescents develop during adolescence. Other factors that influence morale beyond prosocial and religiosity behaviors such as age, socioeconomic class, social relations and personality factors.
\end{abstract}

Keywords: moral, prosocial behavior, religiosity 


\section{PENDAHULUAN}

Penurunan moralitas adalah salah satu isu yang paling penting yang dihadapi oleh masyarakat saat ini. Banyaknya remaja yang tidak memiliki nilai-nilai moral yang merupaka kode etik dan standar hidup yang ditetapkan oleh masyarakat tertentu dalam kehidupan. Kebanyakan individu mengembangkan moral mereka terutama di rumah, melalui pengaruh keluarga dan orang tua mereka yang merupakan kunci sosialisasi pertama yang menanamkan nilai-nilai moral pada anak. Standar perilaku dan nilai-nilai moral dapat berubah dari waktu ke waktu, turun temurun, budaya dan lingkungan (Javed, Kauar, \& Khan, 2014).

Indonesia merupakan negara yang memiliki berbagai macam budaya yang mayoritas masih menganut budaya ketimuran yaitu memegang nilai-nilai moral sangat penting untuk mendukung dalam mengontrol perbuatan individu dan masyarakat dengan lingkungannya. Namun, dengan kemajuan zaman yang serba modern sekarang ini, bisa berdampak positif dan negatif bagi perkembangan moral terutama remaja (Frey, 2009). Masa remaja merupakan masa terjadi perubahan yang sangat pesat dalam dimensi fisik,mental dan sosial. Masa ini juga merupakan periode pencarian identitas diri,sehingga remaja sangat mudah terpengaruh oleh lingkungan. Remaja menunjukkan perilaku sesuai dengan norma dan nilai yang berlaku, maka remaja dikatakan memiliki moralitas. Namun banyak remaja yang tidak menyesuaikan diri dengan norma yang berlaku. Seperti gaya hidup modern saat ini yang digandrungi banyak remaja.

Hasil survey kompasiana (2014) gaya hidup remaja yang serba modern dengan pengaruh budaya barat yang tidak sesuai dengan budaya indonesia membuat remaja di indonesia semakin banyak yang berbuat negative yang tentunya meresahkan berbagai lapisan masyarakat. Hasil-hasil studi terdahulu, menyimpulkan bahwa, individu memerlukan suatu pengontrol diri dalam berpikir, bersikap, bertindak yaitu dengan agama atau religiusitas (Reza, 2013).

Alasan menafsirkan agama secara khusus sebagai salah satu aspek pendidikan moral. Setelah jelas membedakan antara kognitif dan aspek konatif pendidikan moral, yang menunjukkan bagaimana tertentu praktik keagamaan sejarah berfungsi untuk memberikan aspek konatif dalam pendidikan moral. Kant mendefinisikan aspek pendidikan moral sebagai praktek yang membuat manusia gagah berani dan ceria dalam memenuhi tugas-tugasnya (Dennis, 2015).

Menurut Kohlberg, moral ialah internalisasi yakni perubahan perkembangan dari perilaku yang dikendalikan secara eksternal menjadi perilaku yang dikendalikan secara internal (Ugazio, Majdandžić, \& Lamm, 2014). Faktor-faktor yang mempengaruhi moral diantaranya keluarga menurut hasil penelitian yang dilakukan oleh Wheatley \& Haidt (2005) menemukan bahwa remaja yang dirasakan komunikasi positif tinggi dengan orang tua mereka, menunjukkan dapat tercapai tingkat yang lebih besar dari kesepakatan dengan orang 
tua mereka pada isu-isu moral daripada remaja yang dirasakan komunikasi positif rendah dengan orang tua mereka. Faktor empati penelitian yang dilakukan oleh Ugazio, Majdandžić, \& Lamm (2014) menunjukkan bahwa empati terkait secara positif dengan indikator dari moralitas yaitu motivasi. empati dapat memotivasi seseorang untuk membantu orang lain yang membutuhkan.

Faktor prososial dalam penelitian lain yang dilakukan oleh Hardy \& Carlo (2011) prososial membantu untuk hubungan, komunitas, dan masyarakat, Sejumlah prediksi tekstual individu dan contoh perilaku prososial dan antisosial telah diidentifikasi, dan satu prediktor tingkat-individu dari meningkatnya minat adalah identitas moral. Faktor religiousitas berdasarkan hasil penelitian yang dilakukan oleh Dennis (2015) alasan menafsirkan agama secara khusus sebagai salah satu aspek pendidikan moral adalah untuk mengajarkan sesuatu yang diperlukan dan mengubah kerangka berpikir remaja dalam megerjakan tugas dan sikapnya.

Semua agama besar dunia menganjurkan prososial dan mendukung beberapa versi, tidak mengherankan bahwa individu yang menganut agama secara konsisten memiliki tindakan yang lebih prososial bahkan setelah mengendalikan usia, jenis kelamin, pendapatan, pendidikan, dan faktor lainnya (Harrell, 2008).

Hasil penelitian yang dilakukan oleh Harrel (2008) menunjukkan bahwa priming penghargaan terkait konsep positif dampak perilaku prososial, terlepas dari agama konten mereka. Kognisi agama saja tidak cukup untuk memperoleh perilaku prososial reward kognisi harus hadir juga.

Menurut penelitian yang dilakukan oleh Mustea, Negru \& Opre (2010) mengenai religiousitas dan moral memiliki hubungan antara moralitas dan agama dari sudut pandang psikologi moralitas dalam masyarakat, peneliti harus memanfaatkan peran yang dimiliki oleh agama dalam perkembangan moral individu.

Perilaku prososial membantu untuk hubungan, komunitas, dan masyarakat, Sejumlah prediksi tekstual individu dan contoh perilaku prososial dan antisosial telah diidentifikasi, dan satu prediktor tingkat-individu dari meningkatnya minat adalah identitas moral (Hardy \& Carlo, 2011). Orang prima dengan imbalan akan berperilaku lebih prososial, sementara orang-orang prima dengan agama saja tidak akan selalu bertindak lebih prososial.

Semakin terbukti bahwa identitas moral yang dapat memotivasi orang untuk terlibat dalam perilaku prososial dan menjauhkan diri dari perilaku antisosial, tetapi sifat hubungan antara identitas moral dan perilaku seperti masih belum jelas. Mungkin identitas moral yang tidak hanya langsung memprediksi perilaku, tetapi juga moderat hubungan antara kognisi sosial lainnya (misalnya, pelepasan moral dan self-regulation) dan perilaku (Hardy, Bean \& Olsen, 2014). 
Meskipun studi telah meneliti hasil moral remaja (Hardy \& Carlo 2011) ada penelitian untuk pengetahuan telah dilakukan pada remaja untuk menilai peran identitas moral sebagai moderator antara kognitif sosial dan perilaku. Tapi, kurangnya studi remaja ini tidak dalam dan dari dirinya sendiri menjamin studinya. Sebaliknya, ada alasan yang lebih empiris dan substantif lain untuk melihat peran identitas moral yang selama masa remaja. Pertama, masa remaja melihat tarif tinggi terhadap perilaku prososial dan antisosial (Hardy, Bean \& Olsen, 2014).Dengan demikian, pelepasan moral yang tinggi dan rendah selama masa remaja dapat memperburuk tingkat perilaku antisosial dan memadamkan potensi prososial. Identitas moral yang mungkin membantu remaja untuk menjadi yang terbaik yang mereka bisa, dengan meminimalkan perilaku negatif mengenai moral.

Berdasarkan penelitian sebelumnya banyak faktor yang mempengaruhi moral remaja, namun dari semua faktor-faktor diatas faktor perilaku prososial dan religiusitas sangat menarik untuk diteliti. Meskipun data survei selain hubungan moral dengan religiusitas, perilaku prososial menunjukkan sangat terkait dengan religiusitas (Harrell, 2008). Karena hampir semua teori-teori sosial psikologis agama menganggap agama yang positif berdampak pada perilaku prososial.

Adapun tujuan yang ingin dicapai dalam penelitian ini adalah untuk mengetahui hubungan antara perilaku prososial dan religiusitas dengan moral pada remaja

Manfaat dalam penelitian ini secara teoritis, menambah khasanah ilmu pengetahuan psikologi khususnya di bidang psikologi pendidikan dan perkembangan. Manfaat praktis sebagai referensi kepada pendidik dan orang tua agar lebih memperhatikan remaja.

Moral adalah perilaku yang sesuai dengan kode moral kelompok sosial. Moral sendiri berarti tata cara, kebiasaan, dan adat. Perilaku moral dikendalikan konsep konsep moral atau peraturan perilaku yang telah menjadi kebiasaan bagi anggota suatu budaya. Menurut Kohlberg moral ialah internalisasi yakni perubahan perkembangan dari perilaku yang dikendalikan secara eksternal menjadi perilaku yang dikendalikan secara internal, Moral dibagi menjadi tiga tingkatan yaitu prakonvensional, konvensional, pascakonvensional (Ugazio, Majdandžić, \& Lamm, 2014).

Model moral diuraikan oleh Kohlberg berfokus pada dimensi struktural perkembangan moral, independen dari isi masalah moral. Dia mengidentifikasi tiga indikator yang berbeda dari moralitas: (1) moralitas preconventional berdasarkan kendala; (2) moralitas konvensional didirikan pada penghormatan bagi otoritas, aturan dan konvensi; dan (3) moralitas postconventional, terutama berlabuh di moral keadilan (Mustea, Negru \& Opre, 2010).

Prososial adalah perilaku suka rela yang bertujuan untuk mensejahterakan orang lain. Teori psikososial terutama difokuskan pada peran konteks dan faktor sosial terhadap penilaian moral, dan cara di mana hubungan antara penalaran dan perilaku, perilaku dimodelkan oleh faktor-faktor ini. Studi psikologi sosial menunjukkan bahwa setelah individu 
melakukan tindakan tercela, mereka memiliki kecenderungan untuk menemukan rasionalisasi untuk membenarkan (Mustea, Negru \& Opre, 2010).

Eisenberg dan Mussen memberi pengertian perilaku prososial mencakup pada tindakan-tindakan: membagi, kerjasama, menyumbang, menolong, jujur, dermawan, serta mempertimbangkan hak dan kejesahteraan orang lain (Saroglou, 2014). Hubungan moral mempengaruhi prilaku prososial terkait dengan moral pada remaja menunjukkan bahwa priming penghargaan terkait konsep positif dampak perilaku prososial (Harrel, 2008)

Religiusitas adalah tingkat pengetahuan seseorang terhadap agama yang dianutnya serta suatu tingkat pemahaman yang menyeluruh terhadap agama yang dianutnya. Menurut Glock \& Stark ada lima dimensi keberagamaan yaitu ideologis, ritualistic, eksperiensal, konsekuensi, intelektual (Saroglou, 2011). Pengaruh moral terhadap religusitas memiliki hubungan dengan moral dikarenakan moral cenderung mempengaruhi seseorang dalam berpikir, bersikap dan bertindak dalam hubungan sesama manusia akan menjunjung tinggi norma dan nilai agama pada remaja (Dennis, 2015)

Berdasarkan teori perilaku prososial dan religiusitas terhadap moral, dikarekan moral memiliki efek yang besar terhadap sikap dan perilaku seseorang dalam bertindak dan membantu orang lain serta dengan pemahaman agama yang tinggi pada seseorang akan membentuk dan menyeimbangi norma-norma yang sesuai sehingga mampu berperilaku sosial yang diharapkan. Hipotesis dalam penelitian ini adalah ada hubungan antara perilaku prososial dan religiousitas dengan moral pada remaja.

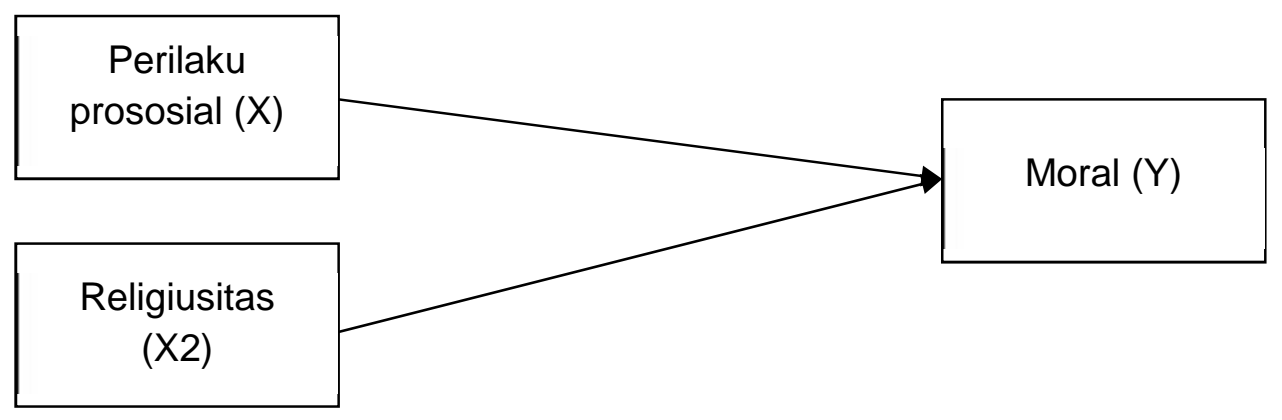

\section{Metode Penelitian}

Penelitian ini menggunakan pendekatan kuantitatif yaitu berupa penelitian causal research adalah desain riset yang bertujuan untuk membuktikan hubungan sebab akibat dari variabel yang diteliti. Penelitian ini menggunakan analisis korelasi ganda yang bertujuan menguji hubungan antara dua atau lebih kelompok variabel dan hubungan antar variabel. Dalam penelitian ini untuk mengetahui adanya hubungan perilaku prososial dan religiousitas dengan moral pada remaja menggunakan bantuan program komputer SPSS (Statistical Program For Social Science) for W indows versi 20,0. 
Penelitian ini menggunakan subjek remaja dengan jumlah 100 orang yang berada di SMP, yang terdiri dari usia 13 sampai 16 tahun. Penelitian ini menggunakan teknik kuota sampling. Prosedur dalam penelitian ini berupa pembagian kuetioner pada remaja yang terdiri dari kuetioner perilaku prososial, reigiusitas dan moral menggunakan skala. Jenis skala yang digunakan adalah skala likert. Skala yang digunakan adalah skala yang telah diuji coba hasil dengan uji reliabilitas skala alpha $>0,7$ artinya reliabilitas mencukupi sementara jika alpha > 0,8 ini mensugestikan seluruh item reliabel dan seluruh tes secara konsisten secara internal karena memiliki reliabilitas yang kuat (Sebastian, 2004).

Skala untuk mengukur moral oleh White's (1997) moral authority scale (MAS-R). Aspek-aspek yang diukur moral internal, moralitas eksternal dan prinsip moralitas. Koefisien reliabilitas $\alpha=0.76$ dengan jumlah 25 aitem. Skala yang digunakan untuk mengukur perilaku prososial yaitu Prosocial Tendencies Measure-Revised (PMTR) oleh Carlo, Hausmann, Christiansen, dan Randall diterjemahkan Akhzalini (2016). Berisi 21 aitem dengan enam aspek yaitu, kerelaan, publik, anonim, menakutkan, emosional, dan altruistik. Koefisien reliabilitas $\alpha=0.710$ (Furman \& Sibthorp, 2013).

Skala religiousitas, diadaptasi dari The Centrality of Religiousity Scale (CSR) yang disusun oleh Huber diterjemahkan Hadi (2016). Skala ini terdiri dari empat aspek religiusitas yaitu aspek keyakinan, praktek agama, pengalaman dan konsekuensi. Total aitem dalam skala ini 18 dengan nilai $\alpha=0.801$. Analisis yang digunakan dalam penelitian ini yaitu analisis korelasi ganda yang digunakan untuk mengetahui adanya hubungan kecerdasan spiritual dan kematangan emosi dengan penyesuaian diri remaja. Sesuai dengan hipotesis dan tujuan penelitian untuk mengetahui hubungan, maka data yang diperoleh akan diuji dengan menggunakan uji syarat yaitu uji normalitas dan uji linieritas.

\section{Hasil dan pembahasan}

Hasil dari penelitian yang dilakukan peneliti menganalisis data yang telah didapatkan. Sebelum menguji hasil penelitian, terlebih dahulu menguji reliabilitas dan validitas dari kuisioner yang digunakan walaupun sebelumnya kuisioner yang digunakan telah teruji reliabilitasnya. Kuisioner moral terdiri dari 25 aitem dengan nilai Cronbach Cronbanch Alpha 0,798 . Kuisioner perilaku prososial terdiri dari 21 dengan Cronbach Alpha 0,815. Sedangkan religiusitas terdiri dari 18 aitem dengan Cronbach Alpha $0,747$. 
Tabel 1. Nilai Cronbach Alpha

\begin{tabular}{|l|c|c|}
\hline \multicolumn{1}{|c|}{ Skala } & J umlah aitem & Nilai Cronbach Alpha \\
\hline Moral & 25 & 0,789 \\
\hline Perilaku prososial & 21 & 0,815 \\
\hline Religiusitas & 18 & 0,747 \\
\hline
\end{tabular}

Sebelum menguji analisis korelasi ganda untuk melihat seberapa besar hubungan variabel bebas terhadap variabel terikat, peneliti terlebih dahulu melakukan uji asumsi syarat yaitu uji normalitas dan uji linieritas. Skala moral dengan perilaku prososial 0,200 dan skala moral dengan religiusitas 0,194 . Uji normalitas yang dilakukan menunjukkan bahwa data berdistribusi normal karena nilai $p>0,05$.

Tabel 2. Uji normalitas

\begin{tabular}{|c|r|r|r|}
\hline Uji normalitas & \multicolumn{1}{|c|}{ Moral } & Perilaku prososial & Religiusitas \\
\hline Asymp. Sig. (2-tailed) & $.200^{\mathrm{c}, \mathrm{d}}$ & $.194^{\mathrm{c}}$ & $.200^{\mathrm{c}, \mathrm{d}}$ \\
\hline
\end{tabular}

Setelah melakukan uji normalitas, peneliti melakukan uji asumsi syarat yang kedua yaitu uji linieritas untuk melihat adanya hubungan yang linier diantara ketiga variabel. Skala moral dengan perilaku prososial 0,000 dan skala moral dengan religiousitas 0,000 hasil uji linieritas menunjukkan bahwa hubungan memiliki hubungan yang linier karena nilai $p<0,05$.

Tabel 3. Uji linearitas

\begin{tabular}{|l|r|r|r|r|r|}
\hline & $\begin{array}{c}\text { Sum of } \\
\text { Squares }\end{array}$ & \multicolumn{1}{c|}{ df } & Mean Square & \multicolumn{1}{c|}{ F } & \multicolumn{1}{c|}{ Sig. } \\
\hline $\begin{array}{l}\text { Moral * perilaku } \\
\text { prososial }\end{array}$ & 958.689 & 1 & 958.689 & 42.408 & .000 \\
\hline $\begin{array}{l}\text { Moral * } \\
\text { religiusistas }\end{array}$ & 828.782 & 1 & 828.782 & 30.989 & .000 \\
\hline
\end{tabular}

Setelah uji asumsi terpenuhi, maka selanjutnya peneliti melakukan uji korelasi, dari tabel korelasi menjelaskan hubungan antara variabel moral dengan perilaku prososial sebesar 0,664 sedangkan hubungan moral dengan religiousitas sebesar 0,617 . Artinya kedua variabel bebas diatas memiliki hubungan positif terhadap variabel terikat. Berdasarkan uji korelasi ganda menjelaskan besar nilai korelasi $(R)$ yaitu sebesar 0,715 dan dijelaskan besarnya hubungan yang disebut koefesien determinan yang merupakan hasil penguadratan R. Dari output tersebut diperoleh koefisien determinan (R2) sebesar 0,511 yang mengandung 
pengertian bahwa pengaruh perilaku prososial dan religiusitas terhadap moral adalah $51,1 \%$ sedangkan sisanya dipengaruhi oleh variabel lain.

Tabel 5. Korelasi

\begin{tabular}{|l|l|r|r|r|}
\hline \multicolumn{2}{|c|}{} & Moral & Perilaku prososial & Religiusitas \\
\hline \multirow{2}{*}{ Moral } & $\begin{array}{l}\text { Pearson } \\
\text { Correlation }\end{array}$ & 1 & $.664^{* *}$ & $.617^{* *}$ \\
\cline { 2 - 5 } & Sig. (2-tailed) & & .000 & .000 \\
\hline
\end{tabular}

Berdasarkan hasil diatas temuan lain juga mendukung pandangan bahwa moral mempengaruhi perilaku prososial dan religusitas. Penelitian yang dilakukan oleh Van IJzendoorn, Bakermans-Kranenburg, Pannebakker, dan Out (2010) hubungan antara faktor iklim moral dan prososial serta perilaku antisosial dalam dan di luar sekolah, menunjukkan bahwa lingkungan sosial memiliki efek yang jauh lebih pada perilaku prososial.

Hasil penelitian Bashori (2017) Hubungan teman sebaya yang positif memberikan kesempatan bagi siswa untuk belajar dan berlatih keterampilan prososial. Interaksi kolaboratif dengan teman sebaya juga diyakini dapat memotivasi pengembangan keterampilan kognitif yang mendukung terbentuknya perilaku prososial. Menurut penelitian Van de Vyver \& Abrams (2017) peningkatan moral juga akan meningkatkan efek perilaku prososial dalam mempromosikan hasil yang berorientasi pada keadilan

Herbert (2003) berpendapat bahwa masyarakat yang memiliki tradisi keagamaan yang berpengaruh dan komprehensif, agama menciptakan ruang wacana inklusif dan efektif yang bahkan mereka yang memiliki komitmen keagamaan lemah dipengaruhi oleh ruang diskursif. Dengan demikian kita dapat mengatakan bahwa sistem bermakna religius mengalir dalam ruang wacana keagamaan dan bahkan mereka yang tidak memiliki komitmen keagamaan atau komitmen keagamaan lemah dipengaruhi.

Hubungan antara agama dan moralitas telah lama diperdebatkan. Apakah agama membuat kita lebih moral. Atau sebaliknya. kategori "agama" dan "moralitas" harus difraksinasi menjadi seperangkat sifat biologis dan psikologis meyakinkan, mengungkapkan yayasan kognitif yang membentuk dan membatasi varian budaya yang relevan (Whitehouse, H and Mckay, R, 2015).

Hasil penelitian Oskuoi\& Ebrahimpour (2015) menunjukkan bahwa semua aspek agama (keyakinan, empiris, ritual dan dimensi hasil) memiliki hubungan yang signifikan dan positif dengan moral. Ada hubungan yang sangat signifikan antara religiusitas dengan moralitas remaja di Madrasah Aliyah Pondok Pesantren kota Palembang (Reza, 2013). 


\section{Penutup}

Berdasarkan penelitian yang telah dilakukan, maka dapat ditarik kesimpulan yaitu semakin tinggi moral pada remaja maka perilaku prososial juga tinggi. Perilaku prososial yang tinggi menunjukkan bahwa remaja tengah mengalami perkembangan moral dalam rentang kehidupannya sebagai manusia. Moral yang tinggi juga mempengaruhi tingginya religiusitas yang tinggi menunjukkan bahwa remaja telah mampu menyesuaikannya. Selain itu, remaja juga menunjukkan bahwa remaja mulai dapat mengembangkan keberfungsian diri secara optimal. Melalui analisis uji regresi sederhana, disimpulkan bahwa terdapat hubungan yang signifikan dan positif antara moral dengan perilaku prososial dan hubungan moral dengan religiusitas. Hubungan yang signifikan menunjukkan moral pada remaja dapat dipengaruhi oleh perilaku prososial dan religiusitas yang remaja kembangkan selama masa remaja. Faktor-faktor lain yang mempengaruhi moral diluar perilaku prososial dan religiusitas seperti usia, kelas sosial ekonomi, relasi sosial dan faktor kepribadian.

Saran peneliti bagi remaja untuk dapat meempertahankan perilaku positif tersebut, sehingga dapat membentuk remaja yang memiliki kepribadian dan norma sopan satun yang diinginkan. Diharapkan kepada orangtua dan guru dapat berpartisipasi dalam membentuk perilaku remaja sesuai dengan harapan yang dicita-citakan 


\section{DAFTAR PUSTAKA}

Akhzalini, H. (2016). Hubungan kelekatan teman sebaya dan perilaku prososial di mediasi oleh empati pada remaja. Tesis.

Bashori, K. (2017). Menyemai perilaku prososial di sekolah. Sukma: J urnal Pendidikan, 1(1), 57-92.

Dennis V, A. (2015). Kant on religious moral education. J urnal

Harrell, A. (2008). Religion, rewards, and prosocial behavior. J urnal

Hardy, S. A., \& Carlo, G. (2011). Moral identity: What is it, how does it develop, and is it linked to moral action. Child Development Perspectives, 5, 212-218.

Hardy, Bean, Olsen. (2014). Moral identity and adolescent prosocial and antisocial behaviors: interactions with moral disengagement and self-regulation

Herbert. D. (2003). Religion and civil society:rethinking public religion in the contemporary world. London: ashgate.

Frey, W, J. (2009). Teaching virtue: Pedagogical implications of moral psychology

Furman, N., \& Sibthorp, J. (2013). The development of prosocial behavior in adolescents: a mixed methods study from nols. J ournal of Experiential E ducation., 20(10) 1-16.

Javed, A., Kausar, R., \& Khan, N. (2014). Effect of school system and gender on moral values and forgiveness in pakistani school children. Malaysian Online J ournal of Educational Sciences, 2(4), 13-24.

Kompasiana (2014). Survey kerusakan moral remaja dan pemuda indonesia. April, 2014

Mustea, Negru, Opre .(2010). Morality and religion: A psychological perspective. J urnal.

Oskuoi, M. H., \& Ebrahimpour, H. (2015). The effect of religion on the moral performance employees in iran insurance of ardabil province. J ournal of Current Research in Science, 3(4), 1.

Reza, I. F. (2013). Hubungan antara religiusitas dengan moralitas pada remaja di madrasah aliyah (MA). J urnal

Saroglou, V. (2011). Believing, bonding, behaving, and belonging: The Big Four religious dimensions and cultural variation. J ournal of Cross-Cultural Psychology, 42, 13201340.

Saroglou, V. (2014). Is religion not prosocial at all?. J ournal.

Sebastian Rainsch. 2004. Dynamic strategic analysis: Demystifying simple success strategies (Wiesbaden: Deutscher Universitasts-Verlag) p.167.

Ugazio, G., Majdandžić, J., \& Lamm, C. (2014). Are empathy and morality linked? Insights from moral psychology, social and decision neuroscience, and philosophy. Empathy in morality, 155-171. 
Van de Vyver, J., \& Abrams, D. (2017). Promoting third-party prosocial behaviour: The potential of moral emotions. In Intergroup Helping (pp. 349-368). Springer International Publishing.

Wheatley, T., \& Haidt, J. (2005). Hypnotic disgust makes moral judgments more severe. Psychological Science, 16, 780-784.

White, F. A. (1997). Measuring the content of moral thought: The Revised Moral Authority Scale (MAS-R). Social Behaviour and Personality, 25(4), 321-334

McKay, R., \& Whitehouse, H. (2015). Religion and morality. Psychological bulletin, 141(2), 447.

Wissink, I. B., Deković, M., Stams, G. J., Asscher, J. J., Rutten, E., \& Zijlstra, B. J. (2014). Moral orientation and relationships in school and adolescent pro-and antisocial behaviors: A multilevel study. The journal of school nursing, 30(3), 216-225.. 